\title{
ERGONOMIC ASPECTS RELATED TO MOBILE AGRICULTURAL MACHINERY OPERATORS
}

\author{
S. O. Vambol' ${ }^{1}$, V. V. Agravat ${ }^{2 *}$, M. M. Kiriyenko ${ }^{1}$, R. Yadav $^{3}$, V. V. Zadorozhnya ${ }^{1}$, R. Swarnkar ${ }^{2}$ \\ ${ }^{1}$ Kharkiv Petro Vasylenko National Technical University of Agriculture, Kharkiv, Ukraine \\ ${ }^{2}$ Anand Agricultural University, Gujarat, India \\ ${ }^{3}$ Junagadh Agricultural University, Gujarat, India \\ *Corresponding email: vishal.agravat@gmail.com
}

Received: 17 August 2020; Accepted: 29 September 2020

Cite as: Vambol, S.O., Agravat, V.V., Kiriyenko, M.M., Yadav, R., Zadorozhnya, V.V., Swarnkar, R. (2020). Ergonomic aspects related to mobile agricultural machinery operators. Labour Protection Problems in Ukraine, 36(3), 10-18.

Ergonomics is the key to make the machine "worker friendly". In this paper, the humble effort is carried out to present the outline of the tractor industry of India as well as Ukraine for the subsequent analysis of the operator's working conditions and negative production factors that affect his health. Experiment was conducted in Ukraine for three different tractor models i.e. HTZ-181, HTZ-200, HTZ-200B. Vibrations were measured at frame between cab brackets (on left side member), cab floor at the operator's feet and cab frame (on rear crossmember at the rear window base) for plowing and harrowing operations. Research of structural elements vibration parameters of some tractor models (for harrowing and plowing operation) showed that the cab frame has the highest vibration activity in the vertical direction with a peak in the octave band with a geometric mean frequency of $16 \mathrm{~Hz}$. In the transverse direction, the tractor frame has the highest vibration acceleration amplitude, while the maximum vibration acceleration amplitude falls on the octave band of $16 \mathrm{~Hz}$, but its value is two times lower than in the vertical direction. It was also observed that the amplitudes of vibration accelerations of the elements of the tested tractors during plowing the field had higher values than during harrowing, but these excesses were not significant. Analysis of the test results shows that the tractors' suspensions have practically the same vibration characteristics, and therefore, it is recommended to conduct further studies of the parameters of general vibration (on the operator's seat) and local vibration (on the steering wheel) in order to assess the tractor operator' working conditions, his safety and develop technical solutions to improve the devices/machines. The study practical value and originality consists in identifying the structural elements of mobile agricultural machinery (for example, tractors) that have the highest vibrations, which affect the operator for their further improvement, but not for replacing the machinery. This approach to improving the working conditions of mobile agricultural machinery operators is driven by the country's weak economy and can be beneficial for developing countries in the face of a lack of funds to purchase new ergonomic machines.

Keywords: harmful labour conditions, ergonomic aspects, vibration, tractor test.

\section{ЕРГОНОМІЧНI АСПЕКТИ РОБОТИ ОПЕРАТОРІВ МОБІЛЬНӦ̈ СІЛЬСЬКОГОСПОДАРСЬКОЇ ТЕХНІКИ}

\author{
С. О. Вамболь ${ }^{1}$, В. В. Аграват ${ }^{2 *}$, М. М. Кірієнко ${ }^{1}$, Р. Ядав ${ }^{3}$, В. В. Задорожня ${ }^{1}$, Р. Сварнкар ${ }^{2}$ \\ ${ }^{1}$ Харківський національний технічний університет сільського господарства імені Петра Василенка, Харків, Україна \\ ²Сільськогосподарський університет Ананда, Гуджарат, Індія \\ ${ }^{3}$ Сільськогосподарський університет Джунагад, Гуджарат, Індія \\ *E-mail для листування: vishal.agravat@gmail.com \\ Отримано: 17 Серпня 2020; Прийнято: 29 Вересня 2020
}

Цитувати як: Vambol, S.O., Agravat, V.V., Kiriyenko, M.M., Yadav, R., Zadorozhnya, V.V., Swarnkar, R. (2020). Ergonomic aspects related to mobile agricultural machinery operators. Labour Protection Problems in Ukraine, 36(3), 10-18.

Ергономіка - ключ до того, щоб зробити машину «зручною для працюючого». У цій статті зроблено спробу представити загальну картину оснащення сільськогосподарської галузі Індії та України мобільною технікою для подальшого аналізу умов праці оператора (тракториста) і негативних виробничих факторів, що впливають на його здоров'я. Експеримент проводився в Україні на трьох різних моделях тракторів: ХТ3-181, ХТЗ-200, ХТЗ-200Б. Вібрації були виміряні на рамі трактора між кронштейнами кабіни, лівим лонжероном, підлогою кабіни під ногами оператора і рамою кабіни на задній поперечній балці біля основи заднього скла під час проведення оранки і боронування. Дослідження параметрів вібрації елементів конструкції деяких моделей тракторів (для операцій оранки і боронування) показало, що рама кабіни має найбільшу віброактивність у вертикальному напрямі з піком в октавній смузі із середньою геометричною частотою 16 Гц. У поперечному напрямі рама трактора має найбільшу амплітуду віброприскорення, при цьому максимальна амплітуда віброприскорення припадає на октавну смугу 16 Гц, але ії значення $є$ удвічі нижчим, ніж у вертикальному напрямі. Також було відмічено, що амплітуди віброприскорень елементів випробовуваних тракторів при оранці поля мали більш високі значення, ніж при боронуванні, але ці перевищення не були значними. Аналіз результатів випробувань показує, що підвіски тракторів мають практично однакові вібраційні характеристики, тому рекомендується проводити подальші дослідження параметрів загальної вібрації (на сидінні оператора) та локальної вібрації (на рульовому колесі) з метою оцінки умов праці оператора, його безпеки і розробки технічних рішень із вдосконалення пристроїв/машин. Практична цінність і оригінальність дослідження полягає у виявленні елементів конструкції мобільної сільськогосподарської техніки (на прикладі тракторів), які мають найбільші вібрації, що впливають на оператора, для їх подальшого удосконалення, але не для заміни техніки. Такий підхід до поліпшення умов праці операторів мобільної сільськогосподарської техніки обумовлений слабкою економікою країни і може бути корисним для країн, що розвиваються в умовах браку коштів для придбання нових ергономічних машин.

Ключові слова: шкідливі умови праці, ергономічні аспекти, вібрація, випробування трактора.

1. Problem statement and analysis of the recent researches and publications.

Ergonomics (also known as Human Engineering) is still a new concept in Indian agriculture. It is necessary to create greater awareness about its contribution in improving the quality of life of workers and operators. The development of more complex machines and the increasing awareness about occupational health and safety aspect have made ergonomics and product safety the dominant consideration in design of tractors and farm equipment. It is important to know how to 
increase the efficiency of human power application in agricultural operation by utilizing ergonomic principles without jeopardizing the health and safety of the workers so as to get maximum benefits.

Ergonomics is defined as the study of the design of a workplace, equipment, machine, tool, product, environment, and system which takes into consideration human being's physical, physiological, biomechanical, and psychological capabilities and optimizes the effectiveness and productivity of work systems while assuring the safety, health, and well being of the workers [1]. In simple way, the aim of ergonomics is to fit the job to the worker, not the worker to the job.

A large percentage of the work force in the world is associated with agriculture and related trades. Agriculture has undergone many changes throughout the ages with rapid industrialization and increased population. In Ukraine, the main types of agricultural work are carried out on mobile agricultural equipment - tractors in a unit with trailed or mounted implements and self-propelled agricultural machines. The Indian farming system continues to utilize manual power, animal power and mechanical power but the utilization of power operated agricultural machinery and implement increased day by day and is capable for doing better quality of field operation. With high degree of mechanization of farm machinery, a safe comfortable environment for the operators is important consideration for getting productivity and customer satisfaction are to be enhanced.

In Ukraine, the mechanization of field work has been introduced for a long time, but all the equipment used has significant wear and tear, which seriously affects the working conditions of the operators. In agricultural enterprises from 2000 to 2011 the number of tractors decreased by $65 \%$, grain harvesters - by $66 \%$, corn harvesters - by $75 \%$. The number of vehicles subject to repair is increasing annually [2]. The current state of the machine and tractor fleet is characterized by a critical state, however, its reproduction in the next 10 years is possible only if the annual purchase of agricultural equipment in the amount of about 22 billion hryvnia. [2].

Farm mechanisation in India is in the initial stages, with the mechanisation level ranging from $40 \ldots 45 \%$, which is very low compared to that in developed economies, where mechanization has reached beyond $90 \%$ (World Bank Open Data 2019, FederUnacoma, PwC) analysis India's farm equipment market is $7 \%$ of the global market, with more than $80 \%$ of the value contribution coming from tractors. The adoption rates of farm equipment have increased as indicated by the sales of tractors sale and the rise in farm power availability (FPA) in the recent past. Domestic sales of tractors have increased from 3 lakh units in FY09 to 7.8 lakh units in FY19, registering a phenomenal CAGR of $10 \%$. In addition to the impressive domestic sales volumes, India has exported 92,095 units of tractors during FY19. Average FPA in India has also risen from $1.1 \mathrm{~kW} / \mathrm{ha}$ in $1995-1996$ to 2.02 $\mathrm{kW} / \mathrm{ha}$ in 2017 - 2018. India is also one of the largest manufacturers of equipment such as tractors, harvesters and tillers [3].

The Indian tractor market is dominated by aboriginal Indian OEMs, namely, Mahindra \& Mahindra, Sonalika, TAFE \& Escorts. Key international tractor manufacturers, namely, John Deere and CNH have been able to penetrate the market \& establish a decent market presence over the two decades after having entered the country in the late 1990s through JVs and establishing their own industrial bases subsequently. At present, tractors being used are the longterm ones. Reason behind it is the characteristics of our farmers. Small and marginal land holdings (less than 2.0 ha) contribute to $86 \%$ of total operational land holdings and cover $47 \%$ of total operated area [4].
A similar situation is observed in Ukraine, namely, the high depreciation of the machine and tractor fleet of agricultural enterprises (over $85 \%$ ) [5].

Due to the imperfection of the agricultural machinery used by most of the parameters that determine the state of working conditions, machine operators are exposed to a complex of adverse production factors.

Therefore, the study purpose is to identify harmful production factors and ergonomic aspects when using mobile agricultural equipment, as well as to establish the patterns of their occurrence and impact on the operator.

\section{Statement of the problem and its solution.}

\subsection{Materials and methods.}

Measurements of the vibration parameters of the structural elements of tractors were carried out when they were performing two main agricultural operations, namely: harrowing and plowing. Before the measurements were taken, the operating mode was determined when the highest vibration of the cabin was observed. This mode corresponded to the movement of tractors in the third gear of the second range at the maximum engine speed. All measurements were performed in this mode in order to ensure comparability of test results. Tests were carried out on tractors HTZ-181, HTZ-200, HTZ-200B.

\subsection{Results and Discussion.}

\subsubsection{Need of comfort.}

Tractor is the main prime mower in the agriculture works. Operating a tractor imposes lots of physical and mental stress upon the operator. The operator needs more comfort during various agricultural operations because they have to bear more noise, dust, and vibration hazards as compare to other peoples. With constant need to improve operator's comfort and safety, progress have been made in subsidizing noise, dust and the emphasis is being diverted to reduce the ride vibration levels. Farm workers functioning as the drivers of agricultural tractors are exposed to noise, dust and whole body vibration which may be extremely severe depending upon such factors as attached farm equipment, speed of travel, condition of fields etc. working under such an environment results in human fatigue, which contributes driving related accidents and others health hazards. Physical agents are forms of energy that can harm the body when exposure takes place. It includes mechanical energy, which impact on the body from noise, vibration and also from dust when working under field's conditions. Others physical agents include hot and cold temperatures which can effect the body's normal internal temperature. They may be specific part of production process or an unwanted by products. Exposure to excessive noise, dust, vibration, extreme temperature and radiation can lead to acute or chronic health effect. Physical working capacity diminishes with age and sex. In the same age and sex group also, there are individual variations due to the weight, nutrition etc. When a person dose physical work, he has to stop the work either due to cardiorespiratory limitations, muscular fatigue or others kinds of problems on his body parts [6].

The most objective criterion for assessing the state of working conditions is the indicators of occupational morbidity of workers, which are formed under the direct influence of unfavourable production factors on them. Therefore, the "leading" position of machine operators among agricultural workers in terms of occupational morbidity is quite understandable. Thus, $53.4 \%$ of all registered occupational diseases and poisonings are accounted for by machine operators, which is 3.8 times higher than the industry average [7].

2.2.2. Dust, noise, vibration problem. The structure of the occupational morbidity of machine operators is formed mainly due to vibration disease $(56.2 \%)$, diseases of the musculoskeletal system $(22.4 \%)$, respiratory system $(9.8 \%)$ 
and hearing $(7.5 \%)$ [8]. Vibration pathology in machine operators begins to form already in the first five years of work on agricultural machinery $(0.1 \%$ of detected cases of vibration disease) and reaches a maximum with more than 25 years of experience $(67.3 \%)$ [8]. Comparative assessment of working conditions on tractors DT-75, DT-75N, DT-75S, K700, K-701A, VT-100 «Volgar», MTZ-80, combine harvesters SK-5M «Niva», RSM-10 «Don-1200», RSM-10 «Don-1500», modernized combine harvesters SK-5ME-1 «Niva-Effect» and new generation equipment such as combine harvesters RSM-101 «VECTOR», RSM-142 «ACROS» showed that when performing all types of field work, the machine operators were exposed to noise, general and local vibration, dust of a complex composition, microclimatic discomfort, the level of which, when using oldstyle equipment, exceeded hygienic standards. Modern technology makes it possible to reduce the intensity of exposure to harmful factors of the working environment to standard values; however, with an increase in the period of its operation, deviations of the corresponding indicators from hygienic standards increase [9].

Dust. Modern agriculture is based on highly efficient equipment, especially high-speed, powerful tractors and agricultural machines. Tractors with mounted and trailed implements allow the mechanization of many agricultural operations. Use of tractors allows farmers to accomplish the main tillage and care of plants in the optimum time without major manual labour. Dust is often unavoidable in agricultural work. As a rule, loosening of the soil results in the formation of dust. The nature of the dust in the air is variable, and depends on meteorological conditions, season, kind of work, type of soil and so on. Dust concentration due to tractor operator can vary from a few $\mathrm{mg} / \mathrm{m}^{3}$ to hundreds of $\mathrm{mg} / \mathrm{m}^{3}$ [10]. Dust may contain dried fecal material, fertilizers, fungal spores, mold, pesticides, and herbicides. During land development and tillage operation, soil dust causes a lot of irritation to the tractor operator. The exposure limit as prescribed by the Swedish National Board of Occupational Safety and Health are $10 \mathrm{mg} / \mathrm{m}^{3}$ and $5 \mathrm{mg} / \mathrm{m}^{3}$ for normal dust and organic dust, respectively.

Effects of dust on health. There is a strong need to generate data and then to take corrective measures to safeguard the health of worker engaged in agricultural activities. Exacerbation of asthma by specific allergens and nonspecific causes has been associated with airborne dust. Several farm antigen exposures can trigger asthma, and they include pollen, storage mites and grain dust. Mucous membrane inflammation is a common reaction to airborne dust in individuals with allergic rhinitis or a history of atopy. Plant parts in grain dust appear to cause mechanical irritation to the eyes, but endotoxin and mycotoxin exposure may also be associated with the inflammation of the eyes, nasal passages and throat. Farmers may be exposed to several different substances that can cause acute pulmonary responses [11]. Polluted air reduces the capacity of red blood cells to carry oxygen to the body. It promotes and aggravates heart, blood and other diseases.

Noise. Noise is unwanted sound. Sound is a form of mechanical energy caused by the vibration of the air. The ear is a remarkable organ. The normal range of hearing begins at approximately 0 decibel, a level at which a person with excellent hearing is able to detect a sound. Typically, a person begins to identify sounds when a level of 10 to $15 \mathrm{~dB}$ is reached; this is the threshold of hearing. The other end of scale is known as the threshold of pain $(140 \mathrm{~dB})$, or the point at which the average person experiences pain. In assessing noise, a special measure called $« \mathrm{dBA} »$ indicates damage to hearing. The $\mathrm{dBA}$ rating is provided for many pieces of agricultural equipment. The higher the $\mathrm{dBA}$ number, the greater the risk of damage to hearing.

Effects of noise on health. Excessive noise has the potential to impair hearing, or even destroy it. Noise may also put stress on other parts of the body causing the abnormal secretion of hormones, the tensing of muscles and other health effect. Sleepleness and fatigue are among the symptoms. Noise also interferes with communication, which can affect normal function including job performance and safety. The specific health effect depends on the types of noise involved and the duration of exposure [12].

Vibration. A particularly important source of danger to which a worker is exposed in machine operation is mechanical vibration. Low frequency ride vibrations in tractor operation affect work output and operator health. Vibration is nothing but it is an oscillation of mass about a 19 fixed point. When a body comes in contact with mechanical sources of vibration the tissues of the body become displaced from their resting position.

Effects of vibration on health. Whole body vibration is transmitted to the body through the supporting surfaces such as the feet, buttocks or back. There are various sources of whole body vibration such as standing on a vibrating platform, floor surface, driving and construction, manufacturing and transportation vehicles. The health effect of whole body vibration on tractor driver are abdominal pain, general feeling of discomfort including headaches, chest pain, nausea, loss of equilibrium (balance), muscle contractions with decreased performance in precise manipulation tasks, shortness of breath, influence on speech, degenerative spinal change, lumbar scoliosis etc. The heavy equipment operators and drivers are particularly at risk for accident and injury due to the above factors [13].

Practical experiences and the literature reveal that the human body is strained much more during driving the tractor under different field conditions and at the same time he exposed to noise, dust, vibration, exhaust fumes, rain, and sunshine, etc. Tractor drivers have lots of problem like pain in shoulder, lower back and buttocks due to the whole body vibration and postural discomfort. Most of the tractor drivers have a temporary threshold shift in hearing due to tractor noise. This exposure to noise could also be a slow and painless way for causing total hearing loss. The health concerns associated with the use of tractor has not been properly documented in our country. It is necessary to study the problem related with tractors operator who is working under different field conditions and it would be helpful in obtaining a proper tradeoff between the human health and engineering.

Thus, among the complex of unfavourable production factors, the determining ones are low-frequency general and medium-frequency local vibration, a forced working posture with significant physical and static muscular tension against the background of an unfavourable microclimate, an increased level of dust and noise.

The human body is most sensitive to frequency ranges $4 \ldots 8 \mathrm{~Hz}$ for vertical vibration and below $2 \mathrm{~Hz}$ for horizontal vibration. Safe exposure limits according to ISO 2631/1 for whole body vibration and ISO 5349 for hand arm vibration is presented as follow (Table 1).

\begin{tabular}{llll}
\multicolumn{3}{l}{ Table $1-$ Safe exposure limits } & {$[14]$} \\
\hline \multirow{2}{*}{$\begin{array}{l}\text { Daily } \\
\text { exposure } \\
\text { time, h }\end{array}$} & $\begin{array}{l}\text { Whole body vibration, } \\
\mathrm{rms}, \mathrm{m} / \mathrm{s}^{2}\end{array}$ & $\begin{array}{l}\text { Hand arm } \\
\text { vibration, } \\
\mathrm{rms}, \mathrm{m} / \mathrm{s}^{2}\end{array}$ \\
\cline { 2 - 4 } & Vertical, az & $\begin{array}{l}\text { Horizontal, } \\
\text { ax and ay }\end{array}$ & $\mathrm{x}, \mathrm{y}$ and $\mathrm{z}$ axis \\
\hline 8 & 0.630 & 0.448 & 2.1 \\
\hline 4 & 1.060 & 0.710 & 2.9 \\
\hline
\end{tabular}


2.2.3. Investigation of vibration parameters of tractor structural elements.

The test results of tractors HTZ-181, HTZ-200, HTZ200B, which harrowed the field, are presented in Tables $2-$
4. Figures $1-3$ show the vibration characteristics of the elements of the HTZ-181 tractor when performing the same technological operation.

Tables 2 - Vibration characteristics of the elements of the HTZ-181 tractor. Operation: harrowing

\begin{tabular}{|c|c|c|c|c|c|c|c|c|c|c|}
\hline \multirow{2}{*}{$\begin{array}{l}\text { Vibration transducer } \\
\text { installation location }\end{array}$} & \multirow{2}{*}{$\begin{array}{l}\text { Direction of } \\
\text { vibration }\end{array}$} & \multicolumn{9}{|c|}{$\begin{array}{l}\text { Vibration acceleration values, } \mathrm{m} / \mathrm{s}^{2} \text { in octane bands with geometric mean } \\
\text { frequencies, } \mathrm{Hz}\end{array}$} \\
\hline & & 1 & 2 & 4 & 5 & 16 & 31.5 & 63 & 125 & 250 \\
\hline \multirow{3}{*}{$\begin{array}{l}\text { Frame between cab brackets, } \\
\text { left side member }\end{array}$} & Vertical & 0.20 & 0.32 & 0.33 & 0.40 & 0.52 & 0.21 & 0.44 & 0.38 & 0.30 \\
\hline & Transverse & 0.18 & 0.29 & 0.11 & 0.18 & 0.50 & 0.22 & 0.91 & 1.3 & 0.52 \\
\hline & Longitudinal & 0.21 & 0.23 & 0.19 & 0.17 & 0.21 & 0.25 & 0.24 & 0.27 & 0.29 \\
\hline \multirow{3}{*}{$\mathrm{Cab}$ floor at the operator's feet } & Vertical & 0.18 & 0.23 & 0.35 & 0.42 & 0.61 & 0.53 & 0.4 & 0.29 & 0.21 \\
\hline & Transverse & 0.22 & 0.31 & 0.17 & 0.16 & 0.14 & 0.11 & 0.82 & 0.80 & 0.22 \\
\hline & Longitudinal & 0.18 & 0.22 & 0.17 & 0.14 & 0.24 & 0.26 & 0.24 & 0.22 & 0.27 \\
\hline \multirow{3}{*}{$\begin{array}{l}\text { Cab frame (rear crossmember } \\
\text { at the rear window base) }\end{array}$} & Vertical & 0.15 & 0.22 & 0.35 & 0.41 & 0.80 & 0.51 & 0.40 & 0.33 & 0.25 \\
\hline & Transverse & 0.30 & 0.48 & 0.39 & 0.4 & 0.42 & 0.21 & 0.19 & 0.35 & 0.07 \\
\hline & Longitudinal & 0.32 & 0.35 & 0.28 & 0.14 & 0.40 & 0.28 & 0.37 & 0.30 & 0.19 \\
\hline
\end{tabular}

Tables 3 - Vibration characteristics of the elements of the HTZ-200 tractor. Operation: harrowing

\begin{tabular}{|c|c|c|c|c|c|c|c|c|c|c|}
\hline \multirow{2}{*}{$\begin{array}{l}\text { Vibration transducer } \\
\text { installation location }\end{array}$} & \multirow{2}{*}{$\begin{array}{l}\text { Direction of } \\
\text { vibration }\end{array}$} & \multicolumn{9}{|c|}{$\begin{array}{l}\text { Vibration acceleration values, } \mathrm{m} / \mathrm{s}^{2} \text { in octane bands with geometric mean } \\
\text { frequencies, } \mathrm{Hz}\end{array}$} \\
\hline & & 1 & 2 & 4 & 5 & 16 & 31.5 & 63 & 125 & 250 \\
\hline \multirow{3}{*}{$\begin{array}{l}\text { Frame between cab brackets, } \\
\text { left side member }\end{array}$} & Vertical & 0.35 & 0.36 & 0.42 & 0.51 & 0.69 & 0.43 & 0.40 & 0.35 & 0.32 \\
\hline & Transverse & 0.25 & 0.36 & 0.21 & 0.21 & 0.48 & 0.30 & 0.42 & 0.55 & 0.28 \\
\hline & Longitudinal & 0.28 & 0.23 & 0.20 & 0.24 & 0.29 & 0.22 & 0.19 & 0.19 & 0.16 \\
\hline \multirow{3}{*}{$\mathrm{Cab}$ floor at the operator's feet } & Vertical & 0.33 & 0.34 & 0.44 & 0.55 & 0.71 & 0.56 & 0.32 & 0.33 & 0.28 \\
\hline & Transverse & 0.28 & 0.38 & 0.19 & 0.22 & 0.15 & 0.19 & 0.54 & 0.64 & 0.30 \\
\hline & Longitudinal & 0.26 & 0.26 & 0.24 & 0.28 & 0.36 & 0.31 & 0.27 & 0.25 & 0.28 \\
\hline \multirow{3}{*}{$\begin{array}{l}\text { Cab frame (rear crossmember } \\
\text { at the rear window base) }\end{array}$} & Vertical & 0.38 & 0.32 & 0.40 & 0.62 & 1.7 & 0.74 & 0.47 & 0.35 & 0.35 \\
\hline & Transverse & 0.36 & 0.44 & 0.27 & 0.34 & 0.41 & 0.22 & 0.43 & 0.41 & 0.23 \\
\hline & Longitudinal & 0.30 & 0.32 & 0.28 & 0.19 & 0.42 & 0.29 & 0.25 & 0.33 & 0.12 \\
\hline
\end{tabular}

Tables 4 - Vibration characteristics of the elements of the HTZ-200B tractor. Operation: harrowing

\begin{tabular}{|c|c|c|c|c|c|c|c|c|c|c|}
\hline \multirow{2}{*}{$\begin{array}{l}\text { Vibration transducer } \\
\text { installation location }\end{array}$} & \multirow{2}{*}{$\begin{array}{l}\text { Direction of } \\
\text { vibration }\end{array}$} & \multicolumn{9}{|c|}{$\begin{array}{l}\text { Vibration acceleration values, } \mathrm{m} / \mathrm{s}^{2} \text { in octane bands with geometric mean } \\
\text { frequencies, } \mathrm{Hz}\end{array}$} \\
\hline & & 1 & 2 & 4 & 5 & 16 & 31.5 & 63 & 125 & 250 \\
\hline \multirow{3}{*}{$\begin{array}{l}\text { Frame between cab brackets, } \\
\text { left side member }\end{array}$} & Vertical & 0.31 & 0.29 & 0.44 & 0.48 & 0.63 & 0.33 & 0.42 & 0.31 & 0.28 \\
\hline & Transverse & 0.29 & 0.39 & 0.19 & 0.21 & 0.43 & 0.19 & 0.54 & 0.61 & 0.33 \\
\hline & Longitudinal & 0.24 & 0.26 & 0.26 & 0.24 & 0.31 & 0.25 & 0.25 & 0.22 & 0.20 \\
\hline \multirow{3}{*}{$\mathrm{Cab}$ floor at the operator's feet } & Vertical & 0.28 & 0.31 & 0.33 & 0.49 & 0.72 & 0.61 & 0.38 & 0.27 & 0.19 \\
\hline & Transverse & 0.21 & 0.29 & 0.16 & 0.19 & 0.13 & 0.09 & 0.45 & 0.56 & 0.33 \\
\hline & Longitudinal & 0.16 & 0.24 & 0.22 & 0.23 & 0.31 & 0.37 & 0.20 & 0.18 & 0.18 \\
\hline \multirow{3}{*}{$\begin{array}{l}\text { Cab frame (rear crossmember } \\
\text { at the rear window base) }\end{array}$} & Vertical & 0.21 & 0.20 & 0.40 & 0.54 & 1.1 & 0.87 & 0.43 & 0.29 & 0.33 \\
\hline & Transverse & 0.28 & 0.34 & 0.39 & 0.42 & 0.39 & 0.24 & 0.13 & 0.22 & 0.12 \\
\hline & Longitudinal & 0.35 & 0.38 & 0.22 & 0.12 & 0.33 & 0.19 & 0.19 & 0.29 & 0.14 \\
\hline
\end{tabular}

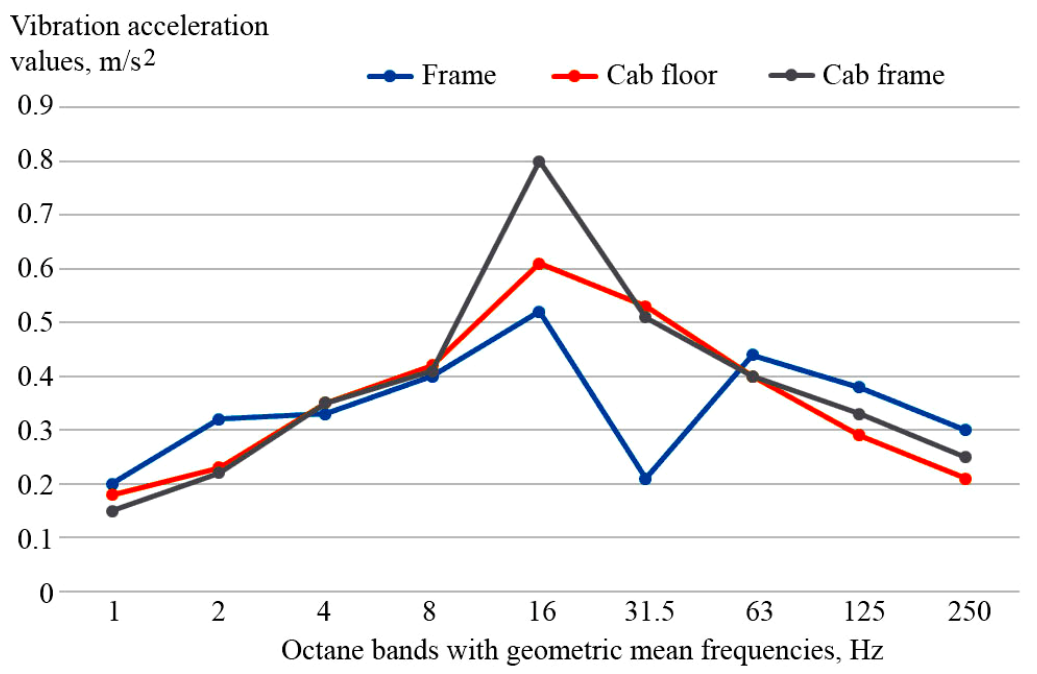

Figure 1 - Vibration characteristics of the elements of the HTZ-181 tractor in the transverse direction. Operation: harrowing 

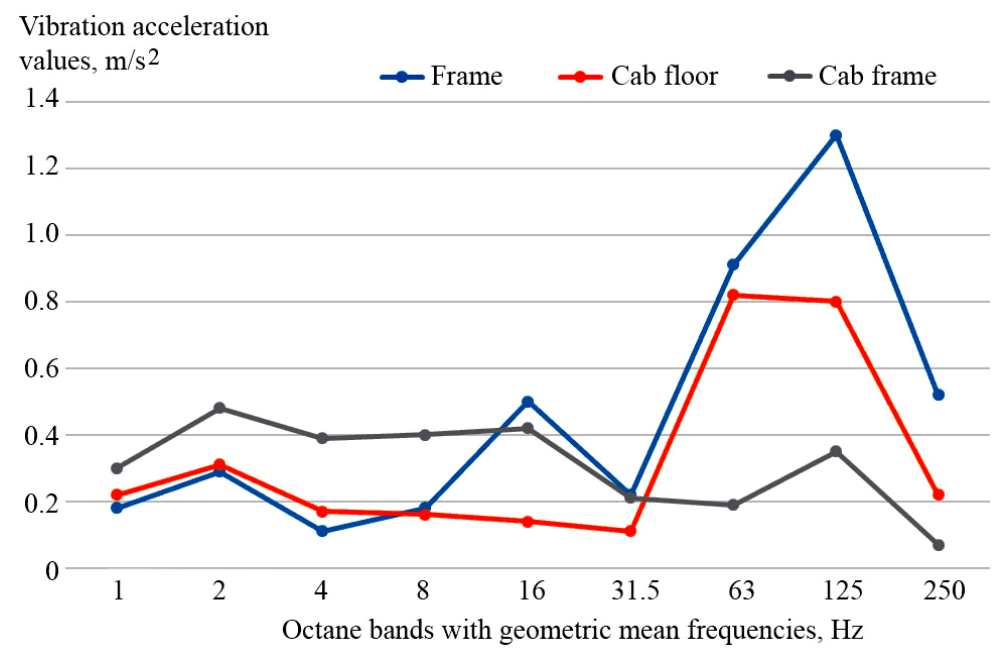

Figure 2 - Vibration characteristics of the elements of the HTZ-200 tractor in the transverse direction. Operation: harrowing

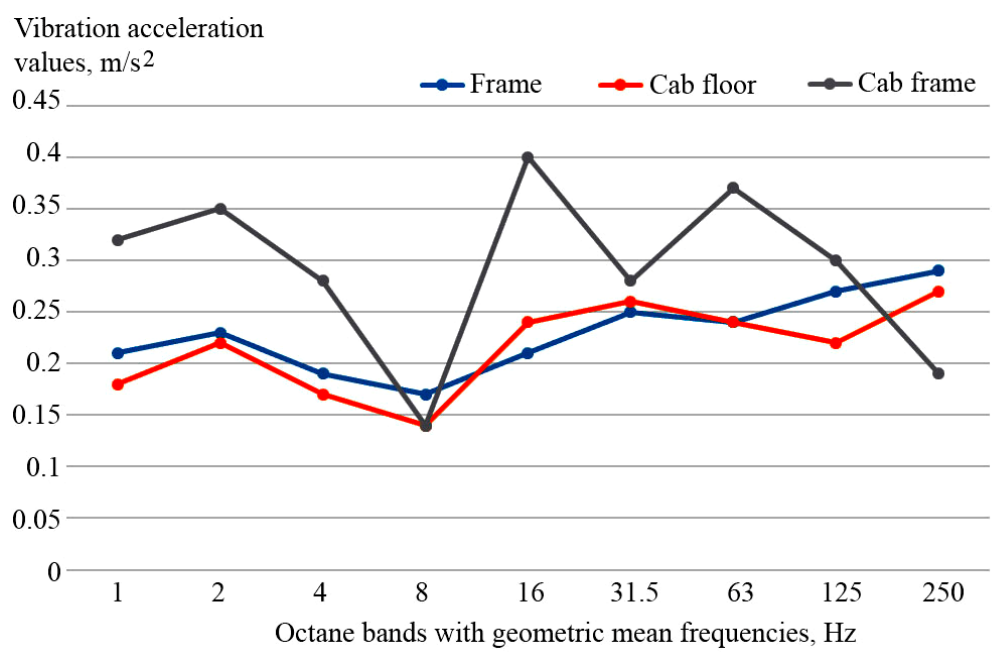

Figure 3 - Vibration characteristics of the elements of the HTZ-200B tractor in the transverse direction. Operation: harrowing

The results show that the cab frame in the vertical direction with a peak in the octave band with a geometric mean frequency of $16 \mathrm{~Hz}$ has the highest vibration activity of the considered structural elements of the HTZ-181 tractor (Table 2 and Figure 1).

The main sources of such vibration can be:

- elements of the running system, namely the impact of the drive wheel teeth on the caterpillar, the frequency of which is

$$
\mathrm{f}=\mathrm{nz},
$$

where $\mathrm{n}-$ the drive wheel rotation frequency, $\mathrm{z}$ - the number of teeth;

- a power unit, the vibration of which is transmitted to the tractor frame with a frequency equal to

$$
\mathrm{f}=\frac{0.5 \cdot \mathrm{n}_{\text {engine }}}{60} \text {. }
$$

The vibration amplitudes of the tractor frame in this octave frequency band are lower than those of the cab elements, which suggest the presence of one of the natural vibration frequencies of the cab, equal to $16 \mathrm{~Hz}$ or close to it. The coincidence of the disturbing frequency with the natural frequency of the body's oscillations always leads to a pronounced resonance (an increase in amplitude by more than 3 times), that is, to a noticeable increase in its vibrational activity, which is also observed in this case. Standard cabin shock absorbers, as shown by measurements, do not work effectively at frequencies close to $16 \mathrm{~Hz}$.

The vibration transmission coefficient in the vertical direction of all three test objects is determined as:

$$
\mathrm{k}=\frac{\mathrm{A}_{\mathrm{C}}}{\mathrm{A}_{\mathrm{F}}},
$$

where $\mathrm{A}_{\mathrm{C}}$ - the value of the vibration acceleration amplitude of the cab frame; $A_{F}$ - value of the vibration acceleration amplitude of the tractor frame.

According to the research results, this coefficient has the values that are presented in Table 5.

Tables 5 - The values of vibration transmission coefficient in the vertical direction

\begin{tabular}{llll}
\hline Test object & HTZ-181 & HTZ-200 & HTZ-200B \\
\hline $\begin{array}{l}\text { Vibration } \\
\text { transmission } \\
\text { coefficient, } \mathrm{k}\end{array}$ & 1.5 & 2.4 & 1.7 \\
\hline
\end{tabular}

Since, due to the different quality of manufacturing and assembly of tractor structural elements, there is a scatter in the values of the oscillation parameters of the sources, there are differences in the intensity of oscillations of the cabins. Therefore, some products are perceived by operators as relatively calm in terms of vibration activity, others as too active.

In the transverse direction, the HTZ-181 tractor frame has the highest vibration acceleration amplitude. In the longitudinal 
direction, as in the vertical direction, the maximum amplitude of vibration acceleration falls on the octave band of $16 \mathrm{~Hz}$, but its value is two times lower than in the vertical one.

From Tables $2-4$ it can be seen that the nature of the construction of the vibration characteristics of the elements of all three tractors performing the harrowing of the field is approximately the same in three directions of measurements.

Tables $6-8$ and in Figures $4-6$ present the test results of tractors when they are plowing. It can be seen from the tables that the vibrations of the same elements of the tractor differ little in character from those that take place when harrowing.

Tables 6 - Vibration characteristics of the elements of the HTZ-181 tractor. Operation: plowing

\begin{tabular}{|c|c|c|c|c|c|c|c|c|c|c|}
\hline \multirow{2}{*}{$\begin{array}{l}\text { Vibration transducer } \\
\text { installation location }\end{array}$} & \multirow{2}{*}{$\begin{array}{l}\text { Direction of } \\
\text { vibration }\end{array}$} & \multicolumn{9}{|c|}{$\begin{array}{l}\text { Vibration acceleration values, } \mathrm{m} / \mathrm{s}^{2} \text { in octane bands with geometric mean } \\
\text { frequencies, } \mathrm{Hz}\end{array}$} \\
\hline & & 1 & 2 & 4 & 5 & 16 & 31.5 & 63 & 125 & 250 \\
\hline \multirow{3}{*}{$\begin{array}{l}\text { Frame between cab brackets, } \\
\text { left side member }\end{array}$} & Vertical & 0.28 & 0.39 & 0.38 & 0.46 & 0.64 & 0.32 & 0.34 & 0.31 & 0.28 \\
\hline & Transverse & 0.20 & 0.29 & 0.21 & 0.18 & 0.59 & 0.20 & 0.88 & 1.8 & 0.49 \\
\hline & Longitudinal & 0.34 & 0.32 & 0.29 & 0.21 & 0.28 & 0.25 & 0.20 & 0.20 & 0.24 \\
\hline \multirow{3}{*}{ Cab floor at the operator's feet } & Vertical & 0.22 & 0.35 & 0.43 & 0.44 & 0.61 & 0.63 & 0.4 & 0.29 & 0.31 \\
\hline & Transverse & 0.22 & 0.31 & 0.17 & 0.16 & 0.14 & 0.11 & 0.82 & 0.80 & 0.22 \\
\hline & Longitudinal & 0.37 & 0.39 & 0.21 & 0.17 & 0.24 & 0.25 & 0.22 & 0.23 & 0.20 \\
\hline \multirow{3}{*}{$\begin{array}{l}\text { Cab frame (rear crossmember } \\
\text { at the rear window base) }\end{array}$} & Vertical & 0.28 & 0.39 & 0.45 & 0.48 & 0.83 & 0.62 & 0.54 & 0.29 & 0.20 \\
\hline & Transverse & 0.38 & 0.43 & 0.31 & 0.41 & 0.54 & 0.37 & 0.29 & 0.32 & 0.10 \\
\hline & Longitudinal & 0.32 & 0.39 & 0.24 & 0.19 & 0.46 & 0.31 & 0.34 & 0.29 & 0.22 \\
\hline
\end{tabular}

Tables 7 - Vibration characteristics of the elements of the HTZ-200 tractor. Operation: plowing

\begin{tabular}{|c|c|c|c|c|c|c|c|c|c|c|}
\hline \multirow{2}{*}{$\begin{array}{l}\text { Vibration transducer } \\
\text { installation location }\end{array}$} & \multirow{2}{*}{$\begin{array}{l}\text { Direction of } \\
\text { vibration }\end{array}$} & \multicolumn{9}{|c|}{$\begin{array}{l}\text { Vibration acceleration values, } \mathrm{m} / \mathrm{s}^{2} \text { in octane bands with geometric mean } \\
\text { frequencies, } \mathrm{Hz}\end{array}$} \\
\hline & & 1 & 2 & 4 & 5 & 16 & 31.5 & 63 & 125 & 250 \\
\hline \multirow{3}{*}{$\begin{array}{l}\text { Frame between cab brackets, } \\
\text { left side member }\end{array}$} & Vertical & 0.27 & 0.46 & 0.44 & 0.50 & 0.69 & 0.40 & 0.32 & 0.24 & 0.20 \\
\hline & Transverse & 0.31 & 0.39 & 0.30 & 0.22 & 0.64 & 0.44 & 0.55 & 0.88 & 0.40 \\
\hline & Longitudinal & 0.30 & 0.25 & 0.23 & 0.42 & 0.30 & 0.23 & 0.18 & 0.17 & 0.20 \\
\hline \multirow{3}{*}{ Cab floor at the operator's feet } & Vertical & 0.33 & 0.44 & 0.52 & 0.58 & 0.80 & 0.74 & 0.52 & 0.27 & 0.30 \\
\hline & Transverse & 0.36 & 0.41 & 0.28 & 0.26 & 0.59 & 0.37 & 0.52 & 0.65 & 0.30 \\
\hline & Longitudinal & 0.28 & 0.34 & 0.30 & 0.33 & 0.32 & 0.30 & 0.24 & 0.20 & 0.22 \\
\hline \multirow{3}{*}{$\begin{array}{l}\text { Cab frame (rear crossmember } \\
\text { at the rear window base) }\end{array}$} & Vertical & 0.25 & 0.48 & 0.49 & 0.43 & 0.99 & 0.63 & 0.48 & 0.31 & 0.20 \\
\hline & Transverse & 0.35 & 0.48 & 0.30 & 0.32 & 0.50 & 0.43 & 0.51 & 0.41 & 0.23 \\
\hline & Longitudinal & 0.31 & 0.27 & 0.30 & 0.24 & 0.51 & 0.42 & 0.35 & 0.31 & 0.28 \\
\hline
\end{tabular}

Tables 8 - Vibration characteristics of the elements of the HTZ-200B tractor. Operation: plowing

\begin{tabular}{|c|c|c|c|c|c|c|c|c|c|c|}
\hline \multirow{2}{*}{$\begin{array}{l}\text { Vibration transducer } \\
\text { installation location }\end{array}$} & \multirow{2}{*}{$\begin{array}{l}\text { Direction of } \\
\text { vibration }\end{array}$} & \multicolumn{9}{|c|}{$\begin{array}{l}\text { Vibration acceleration values, } \mathrm{m} / \mathrm{s}^{2} \text { in octane bands with geometric mean } \\
\text { frequencies, } \mathrm{Hz}\end{array}$} \\
\hline & & 1 & 2 & 4 & 5 & 16 & 31.5 & 63 & 125 & 250 \\
\hline \multirow{3}{*}{$\begin{array}{l}\text { Frame between cab brackets, } \\
\text { left side member }\end{array}$} & Vertical & 0.31 & 0.42 & 0.39 & 0.51 & 0.72 & 0.43 & 0.36 & 0.29 & 0.25 \\
\hline & Transverse & 0.28 & 0.33 & 0.30 & 0.25 & 0.61 & 0.34 & 0.66 & 0.90 & 0.37 \\
\hline & Longitudinal & 0.30 & 0.32 & 0.29 & 0.30 & 0.24 & 0.20 & 0.20 & 0.26 & 0.28 \\
\hline \multirow{3}{*}{ Cab floor at the operator's feet } & Vertical & 0.32 & 0.39 & 0.44 & 0.53 & 0.75 & 0.72 & 0.43 & 0.31 & 0.31 \\
\hline & Transverse & 0.21 & 0.30 & 0.22 & 0.18 & 0.54 & 0.28 & 0.61 & 0.72 & 0.20 \\
\hline & Longitudinal & 0.37 & 0.41 & 0.31 & 0.24 & 0.28 & 0.30 & 0.28 & 0.31 & 0.25 \\
\hline \multirow{3}{*}{$\begin{array}{l}\text { Cab frame (rear crossmember } \\
\text { at the rear window base) }\end{array}$} & Vertical & 0.38 & 0.42 & 0.51 & 0.60 & 0.91 & 0.74 & 0.52 & 0.33 & 0.29 \\
\hline & Transverse & 0.32 & 0.46 & 0.37 & 0.48 & 0.60 & 0.43 & 0.35 & 0.38 & 0.18 \\
\hline & Longitudinal & 0.34 & 0.39 & 0.39 & 0.28 & 0.63 & 0.48 & 0.43 & 0.42 & 0.22 \\
\hline
\end{tabular}

Vibration acceleration
values, $\mathrm{m} / \mathrm{s}^{2}$
$0.8 \longrightarrow$ HTZ-181 tractor $\rightarrow$ HTZ-200 tractor $\rightarrow$ HTZ-200B tractor

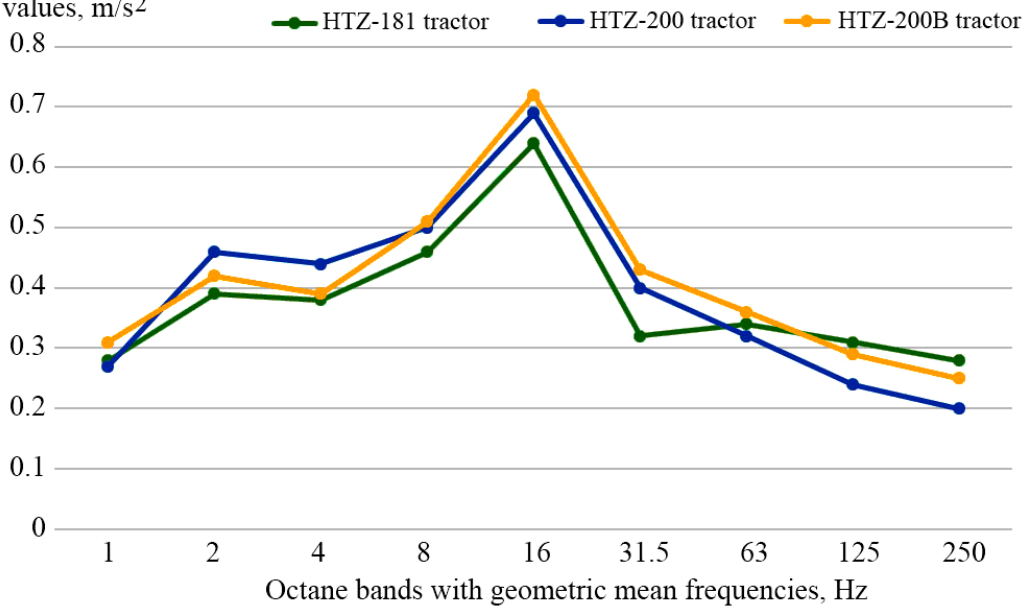

Figure 4 - Vibration characteristics of tractor frames in the transverse direction. Operation: plowing 


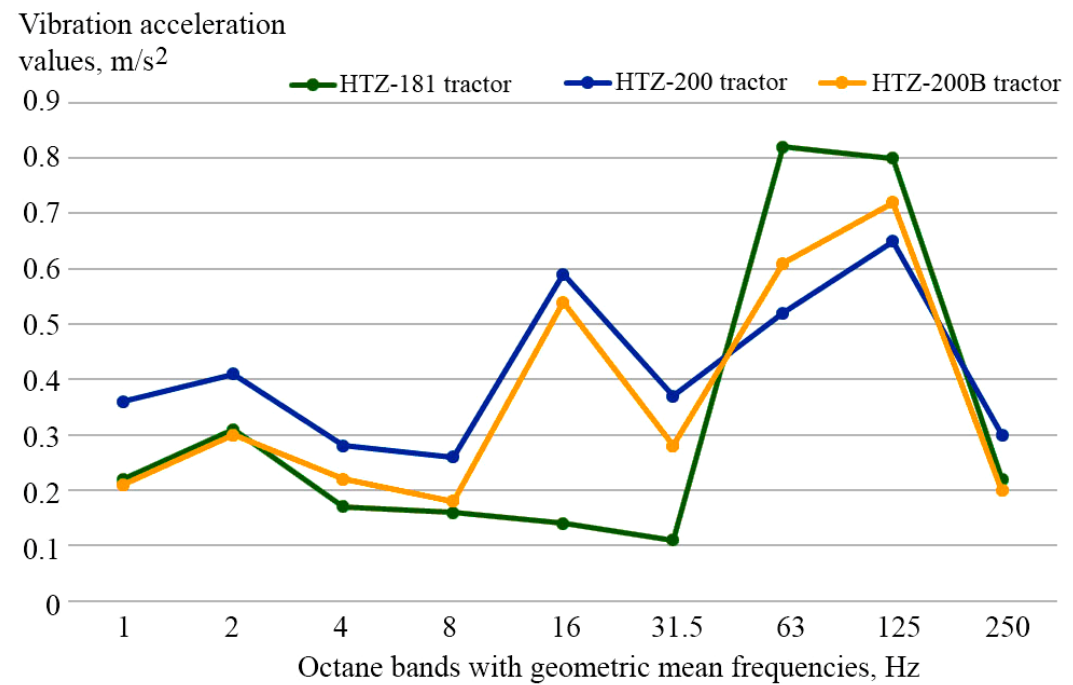

Figure 5 - Vibration characteristics of the tractor cab floor in the transverse direction. Operation: plowing

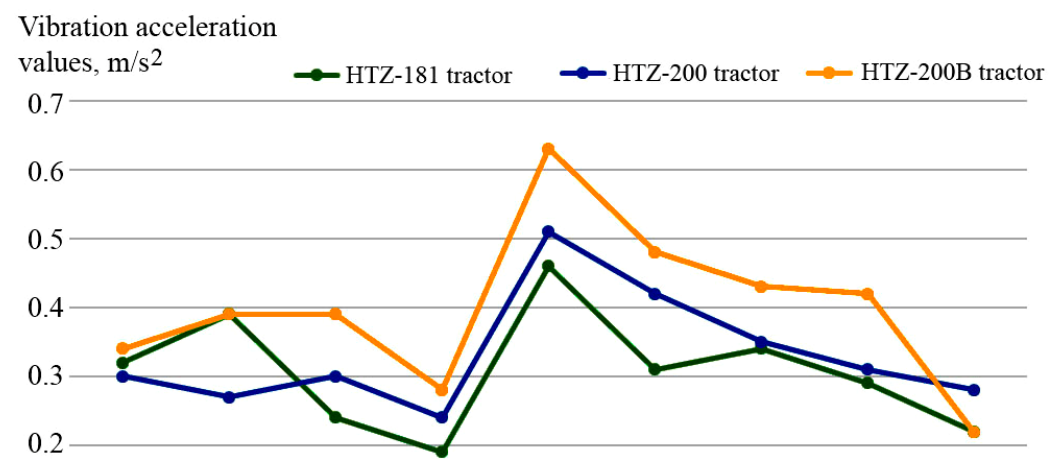

0.1

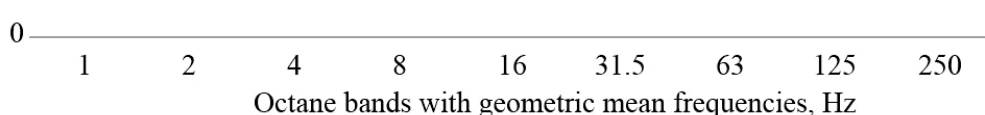

Figure 6 - Vibration characteristics of the tractor cab frame in the transverse direction. Operation: plowing

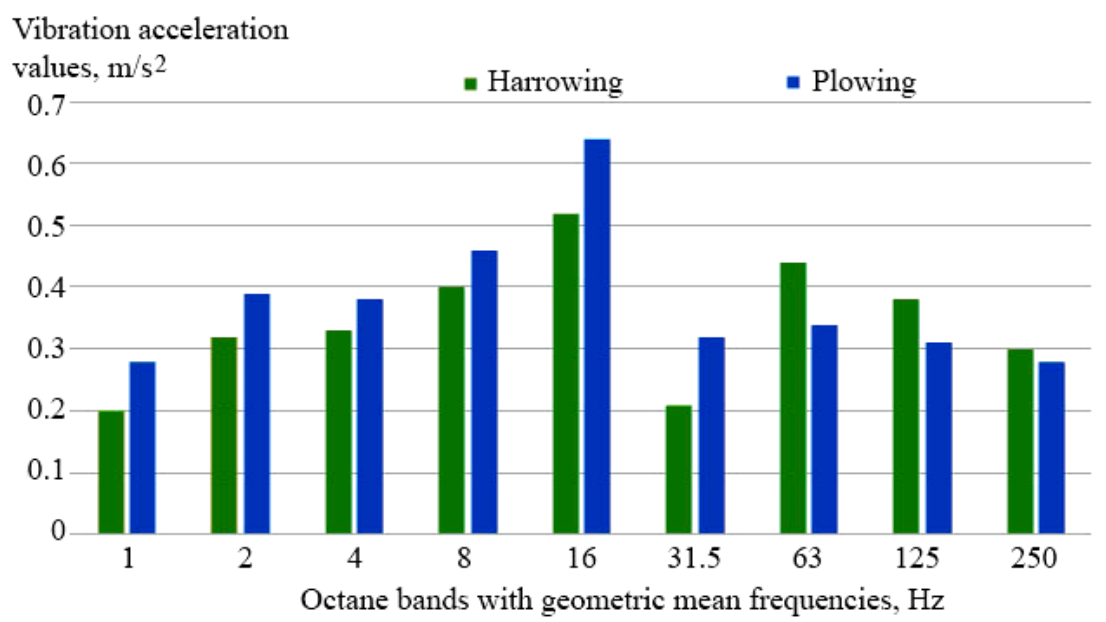

Figure 7 - Vibration characteristics of the frame of the HTZ-181 tractor in the vertical direction 


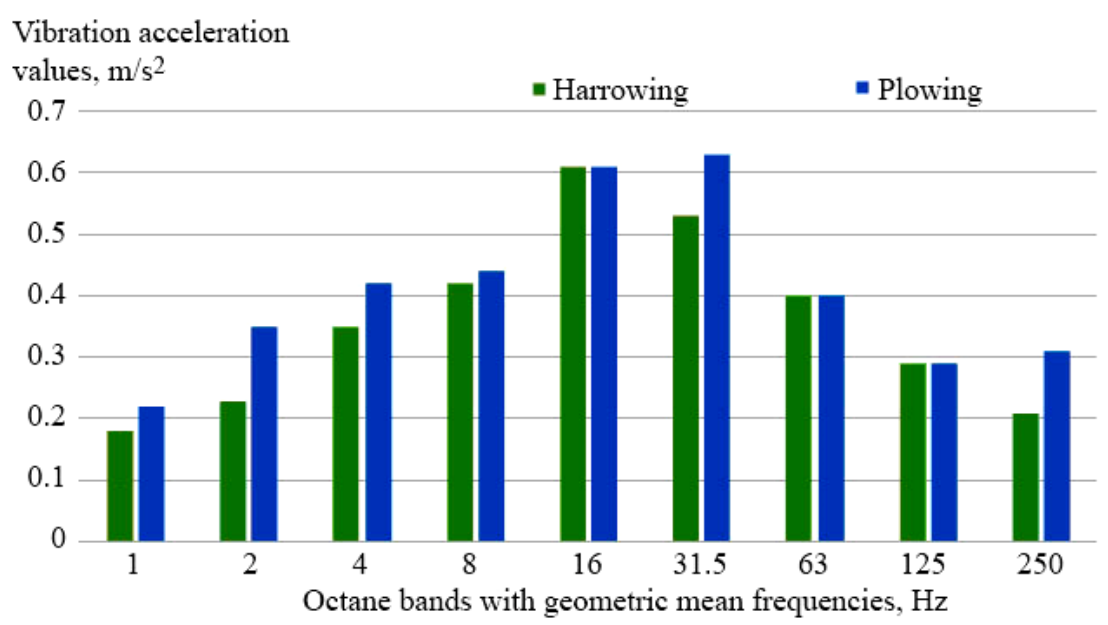

Figure 8 - Vibration characteristics of the cab floor of the HTZ-181 tractor in the vertical direction

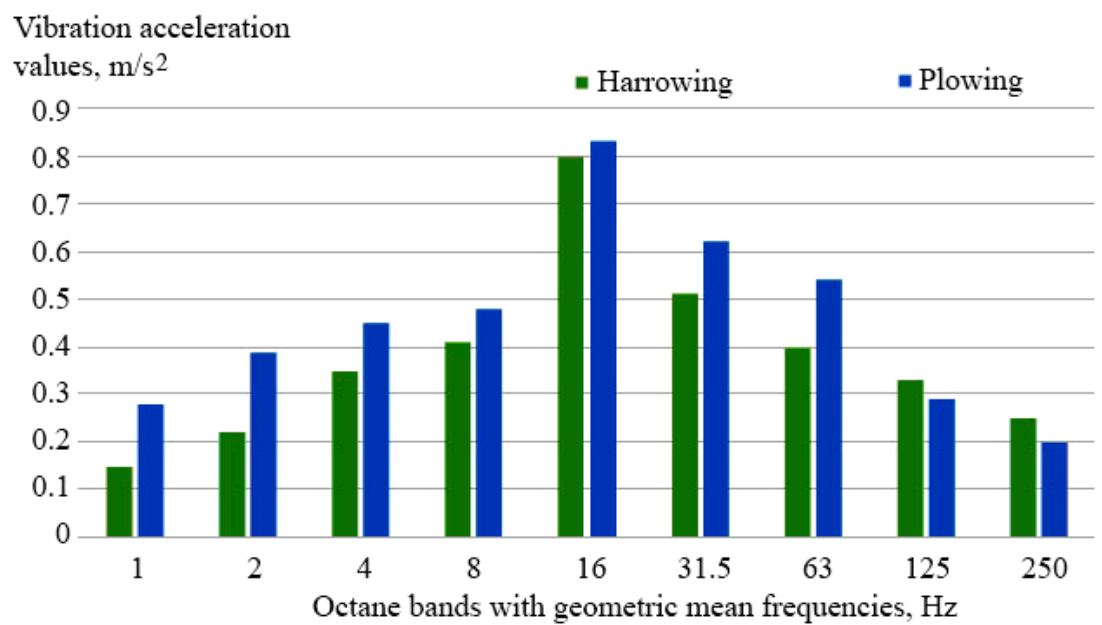

Figure 9 - Vibration characteristics of the cabin frame of the HTZ-181 tractor in the vertical direction

The amplitudes of vibration accelerations of the elements of the tested tractors when plowing the field had higher values than when harrowing, but these excesses were not significant. As an example, Figures $7-9$ show the vibration characteristics of the HTZ-181 tractor elements, taken in the vertical direction.

The analysis of the test results indicates that the tractors' suspensions have practically the same vibration characteristics, which means that the smoothness of the movement of all test objects is at the same level.

In order to assess the working conditions and the safety of the tractor operator, studies of the parameters of general vibration (on the operator's seat) and local vibration (on the steering wheel) should be carried out.

\section{Conclusion and recommendations.}

1. A study of the outline of the tractor industry of India as well as Ukraine showed that the working conditions of mobile agricultural machinery operators are not acceptable, which is mainly due to the not in good condition of the machinery used due to its significant wear.

2. Good ergonomics are helpful in many ways such as workers will feel good about their task, productivity can be increased, Health and safety can be improved and they also got the job satisfaction.

3. It has been established that among the complex of unfavourable production factors that affect the operator of mobile agricultural machinery, the determining ones are lowfrequency general and medium-frequency local vibration, forced working posture with significant physical and static muscle tension in an unfavourable microclimate, increased dust and noise level. Consequently, a workplace without ergonomics causes fatigue as well as disease common musculoskeletal system. The efficiency of solving this problem can be increased by designing (or improving) a devices/machines that are worker friendly.

4. Research of structural elements vibration parameters of some tractor models (for harrowing and plowing operation) showed that the cab frame has the highest vibration activity in the vertical direction with a peak in the octave band with a geometric mean frequency of $16 \mathrm{~Hz}$. In the transverse direction, the tractor frame has the highest vibration acceleration amplitude, while the maximum vibration acceleration amplitude falls on the octave band of $16 \mathrm{~Hz}$, but its value is two times lower than in the vertical direction. It was also observed that the amplitudes of vibration accelerations of the elements of the tested tractors during plowing the field had higher values than during harrowing, but these excesses were not significant.

5. Analysis of the test results shows that the tractors' suspensions have practically the same vibration characteristics, and therefore, it is recommended to conduct further studies of the parameters of general vibration (on the operator's seat) and local vibration (on the steering wheel) in order to assess the 
tractor operator' working conditions, his safety and develop technical solutions to improve the devices/machines.

\section{Acknowledgements.}

The authors would like to thank Kharkiv Petro Vasylenko National Technical University of Agriculture (Kharkiv, Ukraine), Anand Agricultural University (Gujarat, India) and
Junagadh Agricultural University (Gujarat, India) for supporting this study.

\section{Conflicts of Interest.}

The authors declared no potential conflicts of interest with respect to the research, authorship, and/or article publication.

\section{REFERENCES}

1. Fernandez, J.E., Marley, R.J. (1990). Monitoring and screening tests for carpal tunnel syndrome. In Lovesey, E.J. (Ed.), Contemporary Ergonomics 1990. London: Taylor \& Francis, 63-68.

2. Boltyans'ka, N.I., Boltyans'kyy, O.V. (2014). Analiz shlyakhiv pidvyshchennya efektyvnosti vykorystannya mashyno-traktornoho parku. Pratsi TDATU, 14(3), 204-209. Available: http://elar.tsatu.edu.ua/bitstream/123456789/2491/1/31.pdf.

3. Shukla, G.N., Jha, A., Saini, R. (2019). Farm mechanisation: Ensuring a sustainable rise in farm productivity and income. FICCI-PwC, 53 p. Available: http://ficci.in/spdocument/23154/Online_Farm-mechanization-ficci.pdf.

4. Department of Agriculture, Cooperation \& Farmers Welfare, 2018.

5. Makhmudov, I., Panchenko, M. (2018). Onovlennya parku sil's'kohospodars'koyi tekhniky Ukrayiny. Suchasna sotsial'no-ekonomichna systema: paradyhma, zavdannya i tendentsiyi u 2-kh chastynakh: zb. nauk. prats', CH.2, 128-131. Available: http://nati.org.ua/docs/science/2018/ Conference_27042018_p002.pdf\#page=129.

6. Saha, P.N., Datta, S.R., Banerjee, P.K., Narayane, G.G. (1979). An acceptable workload for Indian workers. Ergonomics, 22(9), 1059-1071

7. Rohach, YU.P. (2016). Metodyka rozrakhunku imovirnosti zakhvoryuvan' operatoriv mobil'noyi sil's'kohospodars'koyi tekhniky vid vplyvu pylovoho faktoru. Sciences of Europe, 9(9), 97-100. Available: http://elar.tsatu.edu.ua/bitstream/123456789/3796/1/2-2-5.pdf.

8. Kostyuk, I.F., Kapustnyk, V.A. (2003). Profesiyni khvoroby: pidruchnyk. Kyyiv, «Zdorov'ya», 582 s. Available: http://repo.knmu.edu.ua/ bitstream/123456789/580/3/Profhvoroby.pdf.

9. Novikova, T.A. (2016). Usloviya truda i profilaktika profzabolevaniy u traktoristov-mashinistov: opyt Saratovskoy oblasti. Available: https://www.trudcontrol.ru/press/publications/2658/usloviya-truda-i-profilaktika-profzabolevaniy-u-traktoristov-mashinistov-opit-saratovskoy-oblasti.

10. Stellman, J.M. (Ed.). (1998). Encyclopaedia of occupational healt and safety (Vol. 3). International Labour Organization, Geneva. Available: https://books.google.co.in/books?id=nDhpLa1r144C\&pg=PT190\&lpg=PT190\&dq=Dust+concentration+due+to+tractor+operator+can+vary+from+a+ few+mg/m3+to+hundreds+of +mg/m3\&source=bl\&ots=zORiRXDykV\&sig=ACfU3U1hIMnjhfaHZTjzOkpftYdr 4N5Jg\&hl=en\&sa=X\&ved=2ahUK EwjKy9vD247sAhVuzTgGHfimAaUQ6AEwBHoECAEQAQ\#v=onepage\&q=Dust\%20concentration\%20due\%20to\%20tractor\%20operator\%20can $\% 20$ vary $\% 20$ from $\% 20 \mathrm{a} \% 20 \mathrm{few} \% 20 \mathrm{mg} \% 2 \mathrm{Fm} 3 \% 20$ to $\% 20$ hundreds $\% 20 \mathrm{of} \% 20 \mathrm{mg} \% 2 \mathrm{Fm} 3 \& \mathrm{f}=$ false.

11. Wattie, J.M. (1990). Health aspects of exposure to agricultural dusts. In HSE Conference. COSHH-Engineering controls in agriculture, Stoneleigh, UK, 27 September 1990. Health and Safety Executive. Available: https://www.cabdirect.org/cabdirect/abstract/19922454177.

12. Solecki, L. (1998). The effect of occupational exposure to noise among tractor drivers: assessment based on'noise threshold'. Medycyna pracy, 49(6), 535-544.

13. Taylor, W (1974). The vibration syndrome: introduction. The Vibration Syndrome. Academic Press, London, 22 p.

14. Anonymous (2013). Handbook of agricultural engineering. ICAR Publ. New Delhi. 188 p.

\section{С. А. Вамболь, В. В. Аграват, Н. М. Кириенко, Р. Ядав, В. В. Задорожняя, Р. Сварнкар}

\section{ЭРГОНОМИЧЕСКИЕ АСПЕКТЫ РАБОТЫ ОПЕРАТОРОВ МОБИЛЬНОЙ СЕЛЬСКОХОЗЯЙСТВЕННОЙ ТЕХНИКИ}

Эргономика - ключ к тому, чтобы сделать машину «удобной для работающего». В этой статье сделана попытка представить общую картину оснащения сельскохозяйственной отрасли Индии и Украины мобильной техникой для дальнейшего анализа условий труда оператора (тракториста) и негативных производственных факторов, влияющих на его здоровье. Эксперимент проводился в Украине на трех различных моделях тракторов: ХТЗ-181, ХТЗ-200, ХТЗ-200Б. Вибрации были измерены на раме трактора между кронштейнами кабины, левым лонжероном, полом кабины под ногами оператора и рамой кабины на задней поперечной балке у основания заднего стекла во время проведения вспашки и боронования. Исследование параметров вибрации элементов конструкции некоторых моделей тракторов (для операций вспашки и боронования) показало, что рама кабины имеет наибольшую виброактивность в вертикальном направлении с пиком в октавной полосе со средней геометрической частотой 16 Гц. В поперечном направлении рама трактора имеет наибольшую амплитуду виброускорения, при этом максимальная амплитуда виброускорения приходится на октавную полосу 16 Гц, но ее значение является вдвое низким, чем в вертикальном направлении. Также было отмечено, что амплитуды виброускорений элементов испытываемых тракторов при вспашке поля имели более высокие значения, чем при бороновании, но эти превышения не были значительными. Анализ результатов испытаний показывает, что подвески тракторов имеют практически одинаковые вибрационные характеристики, поэтому рекомендуется проводить дальнейшие исследования параметров общей вибрации (на сиденье оператора) и локальной вибрации (на рулевом колесе) с целью оценки условий труда оператора, его безопасности и разработки технических решений по совершенствованию устройств/машин. Такой подход к улучшению условий труда операторов мобильной сельскохозяйственной техники обусловлен слабой экономикой страны и может быть полезным для развивающихся стран в условиях нехватки средств для приобретения новых эргономичных машин.

Ключевые слова: вредные условия труда, эргономические аспекты, вибрация, испытание трактора. 